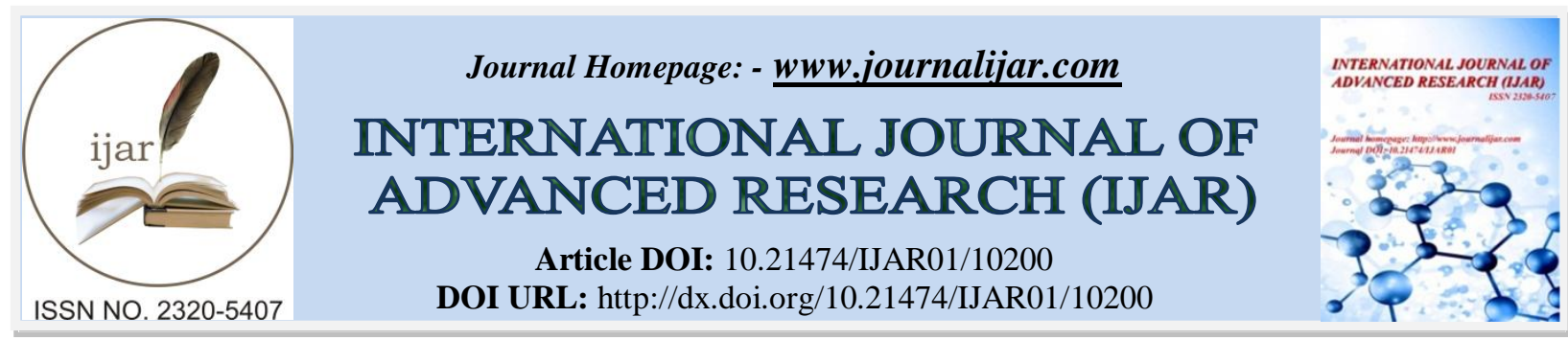

RESEARCH ARTICLE

\title{
FEMINISTIC IDENTITY IN THE GULF OF TRADITIONAL AND MODERN ASPECTS
}

\author{
Priya Adwani and Vastav Shastri \\ 1. Assistant Professor, SDJ International College, Affiliated to VNSGU, Surat. \\ 2. Teaching Assistant SDJ International College, Surat
}

\section{Manuscript Info}

Manuscript History

Received: 10 October 2019

Final Accepted: 12 November 2019

Published: December 2019

Key words:-

Indian Migrant, Identity, Dislocation, New-Self

\begin{abstract}
This paper will explore the various diasporic aspects in the fictions of Jhumpa lahiri especially the short story collections in Interpreter of Maladies (1999) and Unaccustomed Earth (2008) following her first novel The Namesake (2003). It is very significant that Jhumpa Lahiri is the child of Indian migrant and she thinks that the question of identity is always a difficult one for those who are culturally displaced and growing up in two worlds simultaneously. The condition of people living in diaspora is always a dual state which creates confusion and clashes. Identity and sense of dislocation, alienation and other issues that expatriates deal with. Diaspora is all about the creation of new identities in a new cultural space. Lahiri's works manifest the notion of being uprooted from homeland and also put emphasize on the quest for blending in the host country. Her characters try to become a "new- self" without really letting go of the "old - self" and thus creates stories that display universal appeal. Lahiri pursues contradictory ways in handling the issues of diasporic life which makes her writing a delicate and poised voice within the Indian and world diasporic literature.
\end{abstract}

Copy Right, IJAR, 2019,. All rights reserved.

\section{Introduction:-}

"All Diasporas are unhappy, but every diaspora is unhappy in its own way. Diaspora refer to people who do not feel comfortable with their non-hyphenated identities as indicated on their passport...They are precariously lodged within an episteme of real or imagined displacements, self-imposed sense of exile; they are haunted by specters, by ghosts arising from within that encourage irredentist or separatist movements."

- (Vijay Mishra, The Literature of Indian Diaspora: Theorizing the Diasporic imaginary)

There are two different kinds of displacement. Exile describes the predicament of individuals and Diaspora refers to the collective experience of groups of peoples. Exile involves loss of home; diaspora suggests a home-away-fromhome. But there is more to these concepts than simply displacement as traumatic and fundamental as that is. Exile is immediate, brings with it rupture and removal, is forced, and consequently tends to reinforce boundary markers. Diaspora, on the other hand, may be all of those things and it may be chosen, may be inherited. Diaspora might involve being thrown out of homeland, but might equally be a state of stability and settled life. It might involve loss of identity, but it might simply imply a 'different' identity from a dominant, host culture.

Corresponding Author:-Dr. Priya Adwani

Address:-Assistant Professor, SDJ International College, Affiliated to VNSGU, Surat. 
Robin Cohen in the introduction of his book, Global Diasporas: An Introduction explains the ways in which the term diaspora has required a greater cultural significance. Cohen argued that the term not only denotes the Jewish experiences of dislocation and dispersion. He says that it is not only associated with catastrophic origins and their disturbing effects like the jewish history.

Diaspora has been classified variously according to ethnicities, nationalities, culture and lifestyles etc and due to that various categories the space of Diaspora and its theme has become wider and larger for further studies.

But this paper will border its readings on the Diaspora community that Jhumpa Lahiri has written about in her fictions. The paper also proposes a textual analysis of lahiri's works through the lens of diasporic discourse. It will show how the balanced and elegant voice of the Indian - American author has put on a diversity and authenticity on diasporic literature.

Jhumpa Lahiri belongs to the second generation Diaspora community. The writings of the Diaspora writers due to reasons of their movements but the tension of living in betweens reflected through their works as Rushdie says in his essay "The Indian Writer in England", "that our physical alienation from India almost inevitably means that we will not be capable of reclaiming precisely the thing that was lost; that we will, in short, create fictions, not actual cities or villages, but invisible ones, imaginary homelands, Indias of the mind" (Rushdie 1983: 76) Lahiri was born in London in 1967 with the name Nilanjana Sudeshna and she along with her parents move to Rhode Island when she was two because of her father's job as a librarian in the University town. Jhumpa didn't experience life in London much even though it is her birth place and especially when England and India have had a relationship that goes deep into history which America has never had and that brings its own complications and presumptions to the mix and Lahiri thinks that Us is a unique country for the immigrant experience and her general impression is that America, at least for her and the families she knew growing is a more welcoming place. Lahiri talks about displacements and deracination of the immigrants and thinks that almost any American can connect some level to a family background of having come across some ocean. As D. Sujaritha argues on her essay that not all the Diaspora writers are interested in .0 writing the same features of the concept but there are two different kinds as well like the first kinds who wants to locate their writing in their home country and the second kinds who locate themselves in the host country and talks about the changes they gone through and sometimes the developments or dissatisfactions in lives are portrayed through the characters. Lahiri in her writing mostly talks about the cultural clash and the question of identity. Lahiri also tries her best to describe some proper native characters living in India through her own perspective and as readers we can tell she did wonderful job and it shows that even though she was born and brought up in foreign land she is never rooted from her nativeness and that's is something very significant about Diaspora writing. Lahiri has created her space importantly in the Diaspora writing and her fictions tells us a lot about the experiences of the migrant families where we have both the first generations and second generations telling their stories separately and each of them has got that plight of living in a foreign land and for those of the second generations they have got their own difficulties of blending in with the culture of their ancestors and the culture of their own. Lahiri has travelled extensively to India and has experienced the effects of colonialism there as well as experienced the issues of the diaspora as it exists

\section{Paradigm of Rootlessness in 'Namesake'}

Being a foreigner is a sort of life-long pregnancy-A Perpetual wait, a constant burden, a continuous feeling out of sorts. It is an on-going responsibility, a parenthesis in what had once been ordinary life, only to discover that previous life has vanished, replaced by something more complicated and demanding like pregnancy being a foreigner Ashima believes, is something that elicit the same curiosity from strangers, the same combination of pity and respect - (The Namesake, 49-50).

Jhumpa Lahiri does a wonderful job getting the reader into this character's head and feeling for him as he grows up in a culture entirely new to his parents and their attempts to keep the Indian culture true to their children. The novel highlights the confusion, the homesickness and the loneliness of the first generation Indians in a foreign country. Lahiri has written the novel providing sensitivity to both the parents' generations and children's toward both Americans and Indians.

There seems to be a sense of reversal in the attitude of Ashima and Gogol. Ashima who was strongly upholding her native culture earlier in the novel adapts a new way of life after her husband's death. She starts working, learned to 
drive car, pays her own bills and she gets Andalib 24 comfortable in living life alone in American way. She suddenly feels connected to America and calls it her home. In the end we can see she is as American as she is Indian and adapts herself well. On the other hand Gogol who was totally opposing the traditional values has become much easier on the fact. He unknowingly takes up the traditional role after his father died to look after the family and moved back with his mother and sister. He could not turn away the Indianness nor can he embrace American values unquestioningly. Towards the end he appears to be in the in between situation where Gogol and Nikhil culminate into one. He made peace with his present and past.

\section{Paradigm of Rootlessness in 'Interpreter of Maladies'}

Jhumpa Lahiri's Interpreter of Maladies was an international bestseller. The collection includes nine short stories. In each of the stories Lahiri investigated the troubled and controversial position of the dislocated people. Most of the characters in the stories are caught up in problematic situations in order to accommodate themselves in the new place. Some of them could assimilate easily but some were just caught up in between situations ending up with failure. Interpreter of Maladies represents Lahiri's bicultural and bilingual heritage. According to Angelo Monaco in Lahiri's work her characters are almost all translators, insofar as they must make sense of the foreign in order to survive. They shuttle between India and America and as translators attempt to voice feelings of dislocation and search for the happiness they have lost.

In the story Mrs. Sen's we came to know about a young Indian housewife who after her arranged marriage migrates to North America. Her husband is a university professor. Mrs. Sen is perfect example of the people who suffers the consequences of shifting into an unknown land. Mrs Sen resisted herself from assimilation to the new culture. She creates a small scale India in her American house. The foods, the kitchen equipments, her recipes, clothes, books and every other thing recall the life she had back in India. Even though she had left the place, these things bring back the memories. She constantly refers to India as her "home" even after she is settled down in an American household. Mrs Sen starts babysitting an American boy named Eliot whose mother is a working woman unlike herself. Despite of their differences in age, ethnicity both of them developed a kind of solidarity and mutual companionship. They share the same kind of loss and alienation. Eliot misses his mother's love and affection and grows a feeling for his babysitter. In the story we can see that how Mrs Sen is not interested in assimilating with the American culture. She refused to learn driving which is very important thing to know in place like America. But Mrs Sen thinks that India is much better than America because back at home they have a driver for their car and for her "Everything is there". By then Eliot understood that when Mrs. Sen said home, she meant India, not the apartment where she sat chopping vegetables.(Lahiri, 121)

Two things, Eliot learned, made Mrs Sen happy. One was the arrival of a letter from her family. It was her custom to check the mailbox after driving practice. (Lahiri, 22)

"My mother's dead. My father lives in the US'. "But you are Indian, no?" "Yes. "You live in India" - "I don't live anywhere at the moment". - (Lahiri, 328) This dialogue between Kaushik and his neigbour depict the rootlessness Kaushik suffers from. He chose to wander around places and countries and never settles down. His state of mind could not make peace with any place which he can call home. Kaushik from his childhood living here and there which can be a reason he never settled down. Kaushik is different. His mother dies of breast cancer when he was child. His father remarries and started a new life. Kaushik couldn't come to terms with his personal tragedy. He seems lacking the emotion of a human being. He deserts his family and becomes a nomad and finally died in a tsunami in Thailand. Compared to their parent's lives the second generation of Indian Aemricans suffers more from their displacement. They have no choice for their life. Their Indian parents can call India as their homeland and most of them moved back there. But the new generations get torn between these two worlds.

\section{Conclusion:-}

In Jhumpa Lahiri's writing the two worlds of the east and West have been brought together. Her themes such as assimilation, broken relationships, home, exile, dual identity, rootlessness, hybridity gives us better understanding of Lahiri as a Diaspora writer. The stories she tells us says more of her intercontinental journey during which she gets herself accustomed to both Indian and American culture. Her writings are filled with details of traditional Indian names, food descriptions, recipes, Indian dressing styles and rituals. Lahiri here plays as an ambassador of the Indian diaspora. 
Lahiri's view on the Immigrant fiction is very different. And she actually questions the system and thinks that why one would get marginalized for writing about a specific theme. Lahiri thinks that writers have always tended to write about the worlds they come from and it is just so happens that many writers originates from different parts of the world than they end up living in to another, either by choice or for necessity of the circumstances and therefore write about their experiences. The term Diaspora, exile, alienation, belongingness, expatriation are mostly similar to each other in meaning in the world of diaspora writers and they contain some kind of ambiguity in nature and tells about being both a refugee and ambassador in the foreign land. Here diaspora became a mode of cultural production or it can be called a social form where it talks about merging in a different culture creating hybrid identities. Lahiri wanted to construct different kind of picture of the diasporic life for her readers. The fictions discussed in the paper signify this diversity. We as readers are compelled to give a second thought to the state of 'inbetweenness' of the immigrant population. The diasporic space has a unique nature. Lahiri's Andalib 35 characters show both negativity and positivity to their diasporic adventure. She portrays the positive consequences of flexibility and changing lifestyle in immigrant's life. The characters in Unaccustomed Earth experience pain because they live in a marginal position between two cultures. They keep themselves in both the sides of the culture, two traditions and two ideologies which cause identity crisis, rootlessness and conflicts. The way they look at their past and their own native culture determine their future. Again, in the story "Going Ashore" Lahiri told us about kaushik's mother who suffers from breast cancer. None of the relatives or friends in India helped her or motivates her to deal with the situation. The family decided to back in America in order to get out of the distressing behavior of the native people and get some mental peace. Lahiri shows such problems that prove that the old definition of home as a place of safety and peace has changed in the diasporic world. The immigrant experiences have got diversity. Some of the migrated people can release themselves from the bondage of old values and traditions within the diasporic life and enjoy the goodness of assimilation. Too much remembering past like Kaushik will cause people to get stuck in the past and lose the ability to move forward. Forgetting one's native culture is also harmful in a sense and cause tragedy for Diaspora community. Only negotiating between these two spaces can keep positivity in the lives of the immigrants. To conclude, Diaspora not only led to the crossing of borders. It denotes the journey across the less visible boundaries of time, space, ethnicity, traditional values, language etc. The diasporic subjects relocate into a new landscape and creates something afresh. They cannot simply abandon their old lifestyles and traditions and gradually get shifted to the host land also the interplay between the good and bad should be acknowledged in the diasporic space.

\section{References:-}

1. "A Study of Diasporic Sensibility and Acculturation in Jhumpa Lahiri's The Namesake." International Journal of English Language Literature and Humanities. 28 Nov. 2014. Web. 9 Oct. 2015

2. "Jhumpa Lahiri: By the Book." The New York Times. The New York Times, 7 Sept. 2013. Web. 2 June 2015.

3. "Jhumpa Lahiri's Writing Techniques - Varnam." Varnam. 4 May 2008. Web. 4 June 2015.

4. "Change and Loss" Lahiri, Jhumpa. Interview with Christopher Taylor, The Gurdian. (21 june 2008). Web. 19 June 2015

5. "Maladies of Belonging" interview with Vibhuti patel, News week International (20th September 1999) Web. 9 Oct Singh, Shaleen. "Diaspora Literature : A Testimony of Realism." Ezine Articles. Google, 28 July 2008. Web. 7 Aug. 2015.

6. Chotiner, Isaac. "Jhumpa Lahiri." The Atlantic. Atlantic Media Company, 18 Mar. 2008. Web. 3 June 2015.

7. Cohen, Robin. "Four Phase of Diaspora Writing." Global Diasporas an Introduction. 2nd ed. Hoboken: Taylor \& Francis, 2008. Print

8. Farshid, Sima, and Somayeh Taleie. "The Fertile "Third Space" in Jhumpa Lahiri's Stories." IJCLTS International Journal of Comparative Literature and Translation Studies (2013): 1-5. Print.

9. Karthikadevi, C .G. "Diasporic Experiences in Jhumpa Lahiri's Interpreter of Maladies and Unaccustomed Earth." Language in India 15.1930-2940 (2015): 118-27. Print.

10. Lahiri, Jhumpa. Interpreter of Maladies: Stories. First ed. HarperCollins, 1999. Print.

11. Lahiri, Jhumpa. The Namesake. Boston: Houghton Mifflin, 2003. Print.

12. Lahiri, Jhumpa. Unaccustomed Earth. 1st ed. New York: Alfred A. Knopf, 2008. Print.

13. Macwan, Hiral. "Struggle for Identity and Diaspora in Jhumpa Lahiri's the Namesake." International Journal of Humanities and Social Science Invention 3.2319-7722 (2014): 45-49. Print.

14. Monaco, Angelo. "Jhumpa Lahiri. The Interpreter of the New Indian Diaspora." (2015): 73-90. Print.

15. Rana, Sujata. "Diasporic Crisis of Dual Identity in Jhumpa Lahiri's The Namesake." Language in India 10.19302940 (2010): 177-83. Print. 
16. Reimer, David. "Exile, Diaspora, And Old Testament Theology." Scottish Bulletin of Evangelical Theology 28.1 (2010): 3-17. Rutherford House. Web. 17 Aug. 2015.

17. S, Sujaritha. "A Reading of Diaspora Literature." Muse India 64. Muse India. Web. 13 July 2015.

18. Safran, William. "Diasporas in Modern Societies: Myths of Homeland and Return." Diaspora Diaspora: A Journal of Transnational Studies: 83-99. 1991. Print

19. Said, Edward. "Reflections on Exile." Reflections on Exile and Other Essays. Harvard UP, 2000. Print. 